\title{
MODIFIKASI MODEL BAURAN PEMASARAN PLUS TERHADAP VARIABEL PEMBENTUK YANG POSITIF DAN SIGNIFIKAN
}

\author{
MINTO WALUYO \\ Jurusan Teknik Industri UPN “Veteran” Jatim \\ E-mail: aanvicenzo@gmail.com
}

\begin{abstract}
ABSTRAK
PT. X Surabaya adalah outlet toko buku yang bisnis utamanya adalah penjualan buku, untuk itu perusahaan perlu untuk melakukan peningkatan dan pengembangan untuk melihat kompetisi, untuk meningkatkan kepuasan pelanggan dan menjadikan konsumen loyal. Model variable yang diusulkan dalam bauran pemasaran plus disusun oleh variabel (produk, harga, kemudahan mendapatkan produk, distribusi, promosi, lokasi, perbedaan produk yang dijual dan servis), kebijakan korporasi, kebiasaan konsumen, keputusan pembelian, akan meningkatkan dampak ke dalam kesetiaan konsumen kepada PT. X. Hasilnya menunjukkan modifikasi model bauran pemasaran plus memiliki dampak langsung, dampak positif dan signifikan ke variabel Produk sebesar 0.482, model bauran pemasaran plus memiliki dampak langsung, dampak positif dan signifikan ke variabel Harga sebesar 0.343, model bauran pemasaran plus memiliki dampak langsung, dampak positif dan signifikan ke variabel distribusi sebesar 0.48, model bauran pemasaran plus memiliki dampak langsung, dampak positif dan signifikan ke variabel Promosi sebesar 0.641, model bauran pemasaran plus memiliki dampak langsung, dampak positif dan signifikan ke variabel Lokasi sebesar 0.443 .
\end{abstract}

Kata kunci: SEM, bauran pemasaran plus, kebijakan perusahaan, perilaku, kepuasan dan kesetiaan konsumen

\begin{abstract}
PT. X Surabaya is a bookstore outlet that sell the book as its main business, for that company needs to make improvements and development to face the competition, to increase customer satisfaction and ultimately become loyal consumers. Variable proposed model starts from the marketing mix which is formed from the variables (product, price, youth get the product, distribution, promotion, location, diversity of products sold and services), corporate policies, consumer behavior, purchase decision, thus increasing the impact of consumer satisfaction loyal to the PT. X. The results show that modification of Marketing Mix Plus had a direct impact, positive and significant impact on its constituent variables namely Products of 0.482, Marketing Mix Plus had a direct impact, positive and significant impact on the price of its constituent variables of 0.343, Marketing Mix had Plus a direct impact, positive and significant impact on the distribution of its constituent variables 0.48, Marketing Mix Plus had a direct impact, positive and significant impact on its constituent variables namely Promotion of 0.641, Marketing Mix Plus had a direct impact, positive and significant impact on the location of its constituent variables of 0.443 .
\end{abstract}

Key words: SEM, marketing mix plus, corporate policy, behavior, satisfaction and loyalty of customer

\section{PENDAHULUAN}

Era globalisasi dan perkembangan perdagangan dunia telah menyebabkan semakin ketatnya persaingan bagi dunia usaha dalam upaya untuk menembus pasaran yang semakin luas. Persaingan yang ketat dalam perdagangan tidak saja menerpa pada satu jenis perusahaan saja, namun juga berlaku pada hampir semua jenis perusahaan. Untuk meraih posisi yang lebih baik, perusahaan harus memperhatikan kepuasan konsumen dengan cara memberikan pelayanan yang terbaik. Hal ini dapat memberikan keuntungan dalam waktu yang panjang bagi perusahaan tersebut. Kemampuan meningkatkan kepuasan secara terus-menerus merupakan syarat mutlak bagi kelangsungan hidup suatu perusahaan.

PT. $X$ adalah salah satu contoh usaha book store yang menawarkan dan menjual beraneka ragam judul buku. Melihat banyaknya book store yang banyak di kunjungi dan banyaknya persaingan yang ada, maka $P T$. $X$ perlu melakukan perbaikan dan menyusun pemodelan dari variable-variabel mana saja yang signifikan untuk meningkatkan kepuasan dan keloyalan konsumen. Perusahaan memfokuskan pemasaran melalui faktor-faktor bauran pemasaran plus yang variabel pembentuknya produk, harga , distribusi, promosi, lokasi, keragaman produk dan pelayanan, kemudahan mendapat produk ini semua 
adalah stategi mendekatkan pada konsumen. Model pengukurannya secara simultan yang dimulai dari bauran pemasaran,kebijakan perusahaan, perilaku konsumen, keputusan pembelian, kepuasan dan loyalitas konsumen. Sehingga usaha-usaha tersebut nantinya dapat semakin berkembang karena konsumen akan semakin puas dan loyal terhadap PT. $X$. Lokasi PT. $X$ di jalan Basuki Rahmat sangat strategis adalah dasar sebagai variabel lokasi. $P T$. $X$ menjual produk buku yang begitu lengkap hal ini didefinisikan sebagai variabel keanekaragaman produk. Manajemen PT. $X$ sudah melakukan training kerja terhadap karyawannya untuk meningkatkan kemampuan dan pelayanan ini adalah dasar sebagai variabel pelayanan. $P T$. $X$ juga menyediakan vasilitas kemudahan bagi konsumen untuk mendapatkan produk yang dikehendaki dengan mudah dan cepat, dengan aplikasinya berupa alat penunjuk lokasi produk maupun pembelian produk secara online tanpa konsumen yang harus pergi ke toko, ini adalah dasar sebagai penetapan variabel kemudahan mendapatkan produk.

Berdasarkan kondisi yang terjadi maka penelitian ini berusaha memodelkan bauran pemasaran plus, kebijakan perusahaan, perilaku konsumen, keputusan pembelian terhadap kepuasan dan kepuasan dan loyalitas konsumen dan loyalitas konsumen di PT X, nantinya dapat diketahui faktorfaktor mana saja yang tidak signifikan dan yang signifikan yang nantinya sebagai bahan kebijakan manajemen. Tujuan penelitian di PT. X ini adalah untuk mengetahui pengaruh bauran pemasaran plus, kebijakan perusahaan, prilaku konsumen, keputusan pembelian terhadap kepuasan dan loyalitas konsumen di PT. X.

\section{METODE}

Sampling dalam penelitian ini adalah para konsumen PT. X Surabaya. Besarnya sampel yang diperlukan minimum 100 konsumen. Karena dalam penelitian ini menggunakan maximum likelihood estimation data yang dibutuhkan antara 100-200 (Waluyo, 2009). Data dalam penelitian yang didapat dari pengembalian kuesioner yang berisi lengkap sebanyak 100 kuesioner dari penyebaran kuesioner sebanyak 130, sehingga asumsi SEM bahwa data harus $\geq 100$ terpenuhi. Kuesioner yang digunakan menggunakan skala semantic differential.

Uji kesesuaian model dilakukan dengan menggunakan 8 kriteria yang dibandingkan dengan nilai kritis (cut off value) tertentu, sedangkan output dari confirmatory factor analysis. Dari tabel 1 dapat disimpulkan bahwa dimensi-dimensi yang digunakan oleh peneliti belum mencerminkan variabel laten yang dianalisis. Uji validitas konvergen digunakan untuk menentukan apakah setiap indikator yang diestimasi secara valid mengukur dimensi dari konsep yang diujinya. Bila setiap indikator memiliki C.R > 2.SE, hal ini menunjukkan bahwa indikator itu secara valid mengukur apa yang sebenarnya diukur dalam model yang disajikan.

\section{HASIL DAN PEMBAHASAN}

Tabel 1. Regression Weight Measurement Model

\begin{tabular}{llllllll}
\hline & & \multicolumn{1}{c}{ Estimate } & S.E. & C.R. & \multicolumn{1}{c}{ P } & Label \\
\hline $\mathrm{X} 1.1 .2$ & $<---$ & $\mathrm{X} 1.1$ & 0.489 & 0.163 & 3.004 & 0.003 & par_1 \\
$\mathrm{X} 1.1 .1$ & $<---$ & $\mathrm{X} 1.1$ & 1 & & & & \\
$\mathrm{X} 1.4 .2$ & $<---$ & $\mathrm{X} 1.4$ & 2.822 & 1.03 & 2.739 & 0.006 & par_2 \\
$\mathrm{X} 1.4 .1$ & $<---$ & $\mathrm{X} 1.4$ & 1 & & & & \\
$\mathrm{X} 1.2 .2$ & $<---$ & $\mathrm{X} 1.2$ & 1 & & & & \\
$\mathrm{X} 1.5 .1$ & $<---$ & $\mathrm{e} 10$ & 1 & & & & \\
$\mathrm{X} 1.6 .2$ & $<---$ & $\mathrm{X} 1.6$ & 0.616 & 0.178 & 3.458 & $* * *$ & par_3 \\
$\mathrm{X} 1.6 .1$ & $<---$ & $\mathrm{X} 1.6$ & 1 & & & & \\
$\mathrm{X} 1.7 .2$ & $<---$ & $\mathrm{X} 1.7$ & 0.248 & 0.432 & 0.746 & 0.455 & par_4 \\
$\mathrm{X} 1.7 .1$ & $<---$ & $\mathrm{X} 1.7$ & 1 & & & & \\
$\mathrm{X} 1.8 .2$ & $<---$ & $\mathrm{X} 1.8$ & 1.167 & 0.314 & 3.715 & $* * *$ & par_5 \\
$\mathrm{X} 1.8 .1$ & $<---$ & $\mathrm{X} 1.8$ & 1 & & & & \\
$\mathrm{X} 1.4 .3$ & $<---$ & $\mathrm{X} 1.4$ & 2.273 & 0.858 & 2.648 & 0.008 & par_6 \\
$\mathrm{X} 1.7 .3$ & $<---$ & $\mathrm{X} 1.7$ & 1.575 & 0.835 & 1.887 & 0.059 & par_7 \\
$\mathrm{X} 1.7 .4$ & $<---$ & $\mathrm{X} 1.7$ & 2.506 & 1.221 & 3.053 & 0.04 & par_8 \\
$\mathrm{Y} 1.1$ & $<---$ & $\mathrm{Y} 1$ & 1 & & & & \\
$\mathrm{Y} 1.2$ & $<---$ & $\mathrm{Y} 1$ & 0.838 & 0.103 & 8.115 & $* * *$ & par_9 \\
$\mathrm{Y} 1.3$ & $<---$ & $\mathrm{Y} 1$ & 1.084 & 0.131 & 8.255 & $* * *$ & par_10 \\
$\mathrm{Y} 1.4$ & $<---$ & $\mathrm{Y} 1$ & 0.66 & 0.132 & 4.999 & $* * *$ & par_11 \\
$\mathrm{Y} 2.1$ & $<---$ & $\mathrm{Y} 2$ & 1 & & & & \\
$\mathrm{Y} 2.2$ & $<---$ & $\mathrm{Y} 2$ & 0.805 & 0.213 & 0.463 & 0.643 & par_12 \\
$\mathrm{Y} 2.3$ & $<---$ & $\mathrm{Y} 2$ & 1.045 & 0.078 & 0.463 & 0.644 & par_13 \\
$\mathrm{Y} 2.4$ & $<---$ & $\mathrm{Y} 2$ & 1.922 & 0.079 & 0.463 & 0.643 & par_14 \\
$\mathrm{Y} 2.5$ & $<---$ & $\mathrm{Y} 2$ & 1.815 & 0.187 & 0.464 & 0.643 & par_15 \\
$\mathrm{X} 1.3 .2$ & $<---$ & $\mathrm{X} 1.3$ & 0.665 & 0.172 & 3.869 & $* * *$ & par_16 \\
$\mathrm{X} 1.3 .1$ & $<---$ & $\mathrm{X} 1.3$ & 1 & & & & \\
$\mathrm{X} .1$ & $<---$ & $\mathrm{X} 1$ & 1 & & & & \\
$\mathrm{X} 1.2 .1$ & $<---$ & $\mathrm{X} 1.2$ & 0.103 & 0.079 & 1.308 & 0.191 & par_83 \\
\hline $\mathrm{Y} 4.3$ & $<---$ & $\mathrm{Y} 4$ & 0.747 & 0.081 & 9.268 & $* * *$ & par_86 \\
$\mathrm{Y} 4.2$ & $<---$ & $\mathrm{Y} 4$ & 1 & & & & \\
$\mathrm{Y} 4.1$ & $<---$ & $\mathrm{Y} 4$ & 0.498 & 0.087 & 5.731 & $* * *$ & par_88 \\
$\mathrm{Y} 3.2$ & $<---$ & $\mathrm{Y} 3$ & 1.409 & 0.472 & 2.983 & 0.003 & par_92 \\
$\mathrm{Y} 3.1$ & $<---$ & $\mathrm{Y} 3$ & 1 & & & & \\
\hline & & & & & & &
\end{tabular}

Berdasarkan Tabel 1, semua indikator memiliki nilai C.R > 2.SE, kecuali indikator daya tangkap (x1.7.2) dan pemrakarsa (y2.1), yang berarti indikator x1.7.2 dan y2.1 tidak valid, sedangkan 31 indikator lainnya valid mengukur variabel (dimensi) yang diuji.

Berdasarkan hasil uji validitas konvergen, diketahui bahwa indikator daya tangkap (x1.7.2) dan pemrakarsa (y2.1) tidak valid, sehingga 


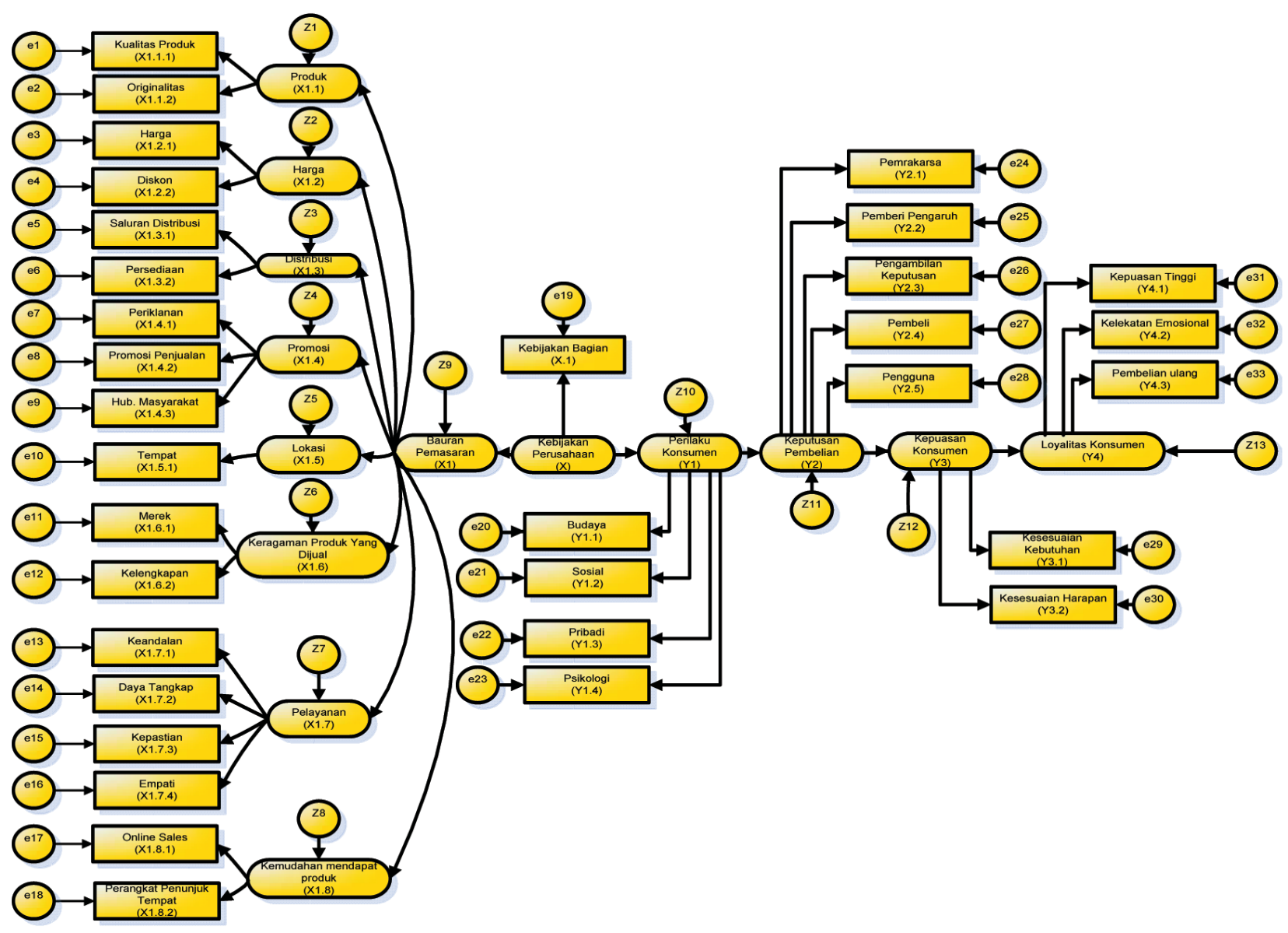

Gambar 1. Kerangka Konseptual bauran pemasaran plus terhadap kepuasan dan loyalitas konsumen di Gramedia Expo Surabaya

indikator tersebut dibuang. Selanjutnya dilakukan pengujian goodness of fit test pada measurement model menggunakan indikator-indikator yang telah dinyatakan valid. Setelah semua indikator dinyatakan valid pada uji validitas konvergen, selanjutnya dilakukan uji validitas diskriminan. Validitas diskriminan dilakukan untuk menguji dua konstruk dengan melihat angka korelasinya. Hubungan kausalitas antar dua variabel terjadi bila kedua variabel tersebut mempunyai hubungan atau angka korelasi antar dua variabel tersebut besar/ signifikan. Sedangkan antar variabel independent harus tidak mempunyai hubungan atau angka korelasi antar kedua variabel tersebut relatif kecil/ tidak signifikan. Hasilnya dan angka korelasi variabel dilihat pada Tabel 2 .

Setelah dilakukan uji validitas diskriminan, selanjutnya dilakukan uji signifikansi. Uji signifikan dapat dilihat melalui nilai lambda atau factor loading $(\lambda)$ dan bobot faktor (regression weight). Berikut adalah nilai goodness of fit indicates dari model persamaan struktural (structural model).
Tabel 2. Angka Korelasi Measurement Model Valid

\begin{tabular}{lllcl}
\hline & & & Estimate & Keterangan \\
\hline $\mathrm{Y} 1$ & $<-->$ & $\mathrm{Y} 2$ & 0.302 & Signifikan \\
$\mathrm{Y} 1$ & $<-->$ & $\mathrm{X} 1$ & 0.369 & Signifikan \\
$\mathrm{Y} 4$ & $<-->$ & $\mathrm{Y} 3$ & 0.916 & Signifikan \\
$\mathrm{Y} 2$ & $<-->$ & $\mathrm{Y} 3$ & 0.274 & Signifikan \\
$\mathrm{X} 1$ & $<-->$ & $\mathrm{X} 1.1$ & 0.560 & Signifikan \\
$\mathrm{X} 1$ & $<-->$ & $\mathrm{X} 1.2$ & 0,400 & Signifikan \\
$\mathrm{X} 1$ & $<-->$ & $\mathrm{X} 1.3$ & 0.680 & Signifikan \\
$\mathrm{X} 1$ & $<-->$ & $\mathrm{X} 1.4$ & 0.250 & Signifikan \\
$\mathrm{X} 1$ & $<-->$ & $\mathrm{X} 1.5$ & 0.400 & Signifikan \\
$\mathrm{X} 1$ & $<-->$ & $\mathrm{X} 1.6$ & 0.279 & Signifikan \\
$\mathrm{X} 1$ & $<-->$ & $\mathrm{X} 1.7$ & 0,791 & Signifikan \\
$\mathrm{X} 1$ & $<-->$ & $\mathrm{X} 1.8$ & 0,571 & Signifikan \\
\hline
\end{tabular}

Tabel 3 dan 4 menunjukkan bahwa hanya adanya kriteria goodness of fit indicates yang mempunyai nilai baik, oleh karena itu model ini belum dapat diterima dengan baik. Oleh karena itu model perlu dimodifikasi hasil modifikasi itulah yang dipakai sebagai kesimpulannya/hasil akhirnya.

Setelah diketahui bahwa hasil uji model modifikasi, maka selanjutnya uji Regression Weight lihat (Tabel 5). 
Tabel 3. Nilai Goodness of Fit dan Cut off Value Structural Model

\begin{tabular}{lccl}
\hline \multicolumn{1}{c}{ Kriteria } & $\begin{array}{c}\text { Hasil Uji } \\
\text { Model }\end{array}$ & Nilai Kritis & Keterangan \\
\hline $\mathrm{X}^{2}$ Chi square & $\begin{array}{l}790,1 \\
\text { (Besar) }\end{array}$ & $\begin{array}{l}\mathrm{X}^{2} \text { dengan } \mathrm{df}=434 \\
\text { dengan } \alpha=0,05 \\
\text { adalah } 483,5705\end{array}$ & Tidak baik \\
Probabilitas & 0,000 & $\geq 0,05$ & Tidak Baik \\
Cmin/DF & 1,82 & $\leq 2,00$ & Baik \\
RMSEA & 0,106 & $\leq 0,08$ & Tidak Baik \\
GFI & 0,667 & $\geq 0,90$ & Tidak Baik \\
AGFI & 0,62 & $\geq 0,90$ & Tidak Baik \\
TLI & 0,512 & $\geq 0,95$ & Tidak Baik \\
CFI & 0,545 & $\geq 0,95$ & Tidak Baik \\
\hline
\end{tabular}

Tabel 4. Nilai Goodness of Fit dan Cut off Value Structural Model Modifikasi

\begin{tabular}{lccc}
\hline \multicolumn{1}{c}{ Kriteria } & $\begin{array}{c}\text { Hasil Uji } \\
\text { Model }\end{array}$ & Nilai Kritis & Keterangan \\
\hline X $^{2}$ Chi square & $\begin{array}{l}694,110 \\
\text { (Kecil) }\end{array}$ & $\begin{array}{l}\mathrm{X}^{2} \text { dengan } \mathrm{df}=635 \\
\text { dengan } \alpha=0,05 \\
\text { adalah } 694,735\end{array}$ & Baik \\
Probabilitas & 0,775 & $\geq 0,05$ & \\
Cmin/DF & 1,74 & $\leq 2,00$ & Baik \\
RMSEA & 0,076 & $\leq 0,08$ & Baik \\
GFI & 0,932 & $\geq 0,90$ & Baik \\
AGFI & 0,919 & $\geq 0,90$ & Baik \\
TLI & 1,024 & $\geq 0,95$ & Baik \\
CFI & 0,976 & $\geq 0,95$ & Baik \\
\hline
\end{tabular}

Berdasarkan Tabel 5, dapat diperoleh hasil pengujian hipotesis sebagai berikut:

\section{Hipotesis Pertama}

Berdasarkan hasil analisis diperoleh bauran pemasaran plus (X1) berpengaruh positif dan signifikan terhadap variabel pembentuknya yakni produk (X1.1) sebesar 0,482 sehingga dinyatakan $\mathrm{H}_{1}$ diterima dan $\mathrm{H}_{0}$ ditolak. Dengan analisis bauran pemasaran plus berpengaruh signifikan terhadap produk/buku yang dijual dengan kualitas baik dan originalitas di PT. X.

\section{Hipotesis Kedua}

Berdasarkan hasil analisis diperoleh bauran pemasaran plus (X1) berpengaruh positif dan signifikan terhadap variabel pembentuknya yakni harga $(\mathrm{X} 1.2)$ sebesar 0,343 sehingga dinyatakan $\mathrm{H}_{1}$ diterima dan $\mathrm{H}_{0}$ ditolak. Dengan analisis bauran pemasaran plus berpengaruh signifikan terhadap harga buku yang dijual dengan harga yang terjangkau dan dikonnya cukup menarik di PT. X.

\section{Hipotesis Ketiga}

Berdasarkan hasil analisis diperoleh bauran pemasaran plus (X1) berpengaruh positif dan signifikan terhadap variabel pembentuknya yakni distribusi (X1.3) sebesar 0,48 sehingga dinyatakan $\mathrm{H}_{1}$ diterima dan $\mathrm{H}_{0}$ ditolak. Dengan analisis bauran pemasaran plus berpengaruh signifikan terhadap distribusi. Dengan analisis bauran pemasaran plus berpengaruh signifikan terhadap distribusi yang mana saluran distribusi bukunya yang baik dan

Tabel 5. Regression Weight dan Standardized Regression Weight Structural Model Modifikasi

\begin{tabular}{|c|c|c|c|c|c|c|c|}
\hline & & & Estimate & S.E. & C.R. & p-value & Standardize Reg, Weight $(\lambda)$ \\
\hline Y1 & $<---$ & $\mathrm{X}$ & 0.199 & 0.078 & 2.554 & 0.011 & 0.236 \\
\hline $\mathrm{Y} 2$ & $<---$ & $\mathrm{Y} 1$ & 0.057 & 0.074 & 0.767 & 0.443 & 0.087 \\
\hline Y3 & $<---$ & $\mathrm{Y} 2$ & 0.208 & 0.124 & 1.674 & 0.094 & 0.261 \\
\hline $\mathrm{X} 1$ & $<---$ & $\mathrm{X} 1$ & 0.157 & 0.135 & 1.158 & 0.247 & 0.325 \\
\hline $\mathrm{X} 1.1$ & $<---$ & $\mathrm{X} 1$ & 0.405 & 0.1 & 4.057 & $* * *$ & 0.482 \\
\hline $\mathrm{X} 1.2$ & $<---$ & $\mathrm{X} 1$ & 0.32 & 0.114 & 2.819 & 0.005 & 0.343 \\
\hline $\mathrm{X} 1.3$ & $<--$ & $\mathrm{X} 1$ & 0.519 & 0.153 & 3.38 & $* * *$ & 0.48 \\
\hline $\mathrm{X} 1.4$ & $<--$ & $\mathrm{X} 1$ & 0.159 & 0.078 & 2.045 & 0.041 & 0.641 \\
\hline X1.5 & $<--$ & $\mathrm{X} 1$ & 0.336 & 0.1 & 3.35 & $* * *$ & 0.443 \\
\hline X1.6 & $<---$ & $\mathrm{X} 1$ & 0.548 & 0.105 & 5.247 & $* * *$ & 0.992 \\
\hline X1.7 & $<---$ & $\mathrm{X} 1$ & 0.196 & 0.123 & 1.592 & 0.111 & 0.194 \\
\hline Y4 & $<---$ & Y3 & 0.675 & 0.261 & 2.585 & 0.01 & 0.288 \\
\hline X1.8 & $<--$ & $\mathrm{X} 1$ & 0.009 & 0.087 & 1.105 & 0.916 & 0.009 \\
\hline $\mathrm{X} 1.1 .2$ & $<--$ & $\mathrm{X} 1.1$ & 0.488 & 0.202 & 2.419 & 0.016 & 0.534 \\
\hline $\mathrm{X} 1.1 .1$ & $<---$ & $\mathrm{X} 1.1$ & 1 & & & & 1.029 \\
\hline Y4.2 & $<---$ & $\mathrm{Y} 4$ & 0.749 & 0.079 & 9.433 & $* * *$ & 0.688 \\
\hline Y4.1 & $<---$ & $\mathrm{Y} 4$ & 1 & & & & 0.996 \\
\hline $\mathrm{X} 1.4 .2$ & $<--$ & $\mathrm{X} 1.4$ & 2.35 & 1.015 & 2.315 & 0.021 & 0.66 \\
\hline $\mathrm{X} 1.4 .1$ & $<--$ & $\mathrm{X} 1.4$ & 1 & & & & 0.306 \\
\hline $\mathrm{X} 1.2 .1$ & $<--$ & $\mathrm{X} 1.2$ & 1 & & & & 0.997 \\
\hline $\mathrm{X} 1.5 .1$ & $<---$ & $\mathrm{X} 1.5$ & 1 & & & & 0.996 \\
\hline
\end{tabular}


Lanjutan Tabel 6.

\begin{tabular}{lllllllc}
\hline & & & Estimate & S.E. & C.R. & p-value & Standardize Reg, Weight $(\lambda)$ \\
\hline X1.6.2 & $<---$ & X1.6 & 0.699 & 0.215 & 3.255 & 0.001 & 0.417 \\
$\mathrm{X} 1.6 .1$ & $<---$ & $\mathrm{X} 1.6$ & 1 & & & & 0.622 \\
$\mathrm{X} 1.7 .1$ & $<---$ & $\mathrm{X} 1.7$ & 1 & & & & 0.998 \\
$\mathrm{X} 1.8 .2$ & $<---$ & $\mathrm{X} 1.8$ & 0.003 & 0.193 & 1.017 & 0.987 & 0.003 \\
$\mathrm{X} 1.8 .1$ & $<---$ & $\mathrm{X} 1.8$ & 1 & & & & 0.998 \\
$\mathrm{X} 1.4 .3$ & $<---$ & $\mathrm{X} 1.4$ & 2.378 & 1.014 & 2.345 & 0.019 & 0.659 \\
$\mathrm{X} 1.7 .3$ & $<---$ & $\mathrm{X} 1.7$ & 0.001 & 0.067 & 1.017 & 0.987 & 0.001 \\
$\mathrm{X} 1.7 .4$ & $<---$ & $\mathrm{X} 1.7$ & 0.002 & 0.06 & 1.032 & 0.975 & 0.002 \\
$\mathrm{Y} 1.1$ & $<---$ & $\mathrm{Y} 1$ & 1 & & & & 0.841 \\
$\mathrm{Y} 1.2$ & $<---$ & $\mathrm{Y} 1$ & 0.834 & 0.102 & 8.195 & $* * *$ & 0.791 \\
$\mathrm{Y} 1.3$ & $<---$ & $\mathrm{Y} 1$ & 1.044 & 0.126 & 8.266 & $* * *$ & 0.782 \\
$\mathrm{Y} 1.4$ & $<---$ & $\mathrm{Y} 1$ & 0.63 & 0.129 & 4.892 & $* * *$ & 0.511 \\
$\mathrm{Y} 2.2$ & $<---$ & $\mathrm{Y} 2$ & 1 & & & & 0.761 \\
$\mathrm{Y} 2.3$ & $<---$ & $\mathrm{Y} 2$ & 1.104 & 0.201 & 5.493 & $* * *$ & 0.8 \\
$\mathrm{Y} 2.4$ & $<---$ & $\mathrm{Y} 2$ & 1.118 & 0.266 & 4.21 & $* * *$ & 0.559 \\
$\mathrm{Y} 2.5$ & $<---$ & $\mathrm{Y} 2$ & 0.92 & 0.18 & 5.112 & $* * *$ & 0.736 \\
$\mathrm{Y} 3.2$ & $<---$ & $\mathrm{Y} 3$ & 1.626 & 0.77 & 2.113 & 0.035 & 0.969 \\
$\mathrm{Y} 3.1$ & $<---$ & $\mathrm{Y} 3$ & 1 & & & & 0.463 \\
$\mathrm{X} 1.3 .2$ & $<---$ & $\mathrm{X} 1.3$ & 0.727 & 0.092 & 7.89 & $* * *$ & 0.621 \\
$\mathrm{X} 1.3 .1$ & $<---$ & $\mathrm{X} 1.3$ & 1 & & & & 0.998 \\
$\mathrm{X} 1$ & $<---$ & $\mathrm{X} 1$ & 1 & & & & 0.996 \\
$\mathrm{X} 1.2 .2$ & $<---$ & $\mathrm{X} 1.2$ & 0.103 & 0.079 & 1.31 & 0.19 & 0.131 \\
$\mathrm{Y} 4.3$ & $<---$ & $\mathrm{Y} 4$ & 0.493 & 0.122 & 4.025 & $* * *$ & 0.373 \\
\hline
\end{tabular}

adanya persedian buku yang cukup sehingga bila ada konsumen beli banyak tersedia di PT. X.

\section{Hipotesis Keempat}

Berdasarkan hasil analisis diperoleh bauran pemasaran plus (X1) berpengaruh positif dan signifikan terhadap variabel pembentuknya yakni promosi (X1.4) sebesar 0,641 sehingga dinyatakan $\mathrm{H}_{1}$ diterima dan $\mathrm{H}_{0}$ ditolak. Dengan analisis bauran pemasaran plus berpengaruh signifikan terhadap promosi.Tiga promosi yakni periklanan,promosi penjualan dan hubungan masyarakat sudah cukup signifikan untuk menarik konsumen membeli buku di PT. X.

\section{Hipotesis Kelima}

Berdasarkan hasil analisis diperoleh bauran pemasaran plus (X1) berpengaruh positif dan signifikan terhadap variabel pembentuknya yakni lokasi (X1.5) sebesar 0,443 sehingga dinyatakan $\mathrm{H}_{1}$ diterima dan $\mathrm{H}_{0}$ ditolak, Dengan analisis bauran pemasaran plus berpengaruh signifikan terhadap lokasi yang mana lokasi PT. X dijalan Basuki Rahmat cukup srategis.

\section{Hipotesis Keenam}

Berdasarkan hasil analisis diperoleh bauran pemasaran plus (X1) berpengaruh langsung, positif dan signifikan terhadap variabel pembentuknya yakni keragaman produk (X1.6) sebesar 0,992 sehingga dinyatakan $\mathrm{H}_{1}$ diterima dan $\mathrm{H}_{0}$ ditolak. Dengan analisis bauran pemasaran plus berpengaruh signifikan terhadap keragaman produk/buku yang dijual dengan penerbit yang terkenal/bermerek dan lebih lebih lengkap sehigga konsumen merasa puas dan loyal membeli buku di PT. X.

\section{Hipotesis Ketujuh}

Berdasarkan hasil analisis diperoleh bauran pemasaran plus (X1) tidak berpengaruh langsung, positif dan tidak signifikan terhadap variabel pembentuknya yakni pelayanan (X1.6) sebesar 0,194 sehingga dinyatakan $\mathrm{H}_{0}$ diterima dan $\mathrm{H}_{1}$ ditolak. Bauran pemasaran plus tidak berpengaruh signifikan terhadap variable pelayanan ini disebabkan karena konsumen masih mencari-cari tambahan koleksi bukunya disebabkan penataan buku yang begitu rapi dan suasana menyenangkan dan terasa nyaman berada di PT. X sehingga fasilitas pelayanan/SPG kurang optimal dimanfaatkan.

\section{Hipotesis Kedelapan (H-8)}

Berdasarkan hasil analisis diperoleh bauran pemasaran plus (X1) tidak berpengaruh langsung, positif dan tidak signifikan terhadap variabel pembentuknya yakni Kemudahan Mendapat 
Produk (X1.8) sebesar 0,009 sehingga dinyatakan $\mathrm{H}_{0}$ diterima dan $\mathrm{H}_{1}$ ditolak. Bauran pemasaran plus tidak berpengaruh signifikan terhadap kemudahan mendapatkan produk, ini disebabkan karena konsumen masih mencari-cari tambahan koleksi bukunya mengingat penataan buku yang begitu rapi dan suasana menyenangkan menyebabkan terasa nyaman berada di PT. X sehingga fasilitas kemudahan mendapatkan produk tidak optimal dimanfaatkan.

\section{Hipotesis Kesembilan (H-9)}

Berdasarkan hasil analisis diperoleh kebijakan perusahaan (X) berpengaruh langsung, positif dan signifikan terhadap bauran pemasaran plus (X1) sebesar 0,325 sehingga dinyatakan $\mathrm{H}_{1}$ diterima dan $\mathrm{H}_{0}$ ditolak. Dengan analisis kebijakan perusahaan (X) berpengaruh signifikan terhadap bauran pemasaran plus (X1),kebijakan bagian sudah cukup signifikan untuk menarik konsumen membeli buku di PT. X.

\section{Hipotesis Kesepuluh}

Berdasarkan hasil analisis diperoleh kebijakan perusahaan $(\mathrm{X})$ berpengaruh positif dan signifikan terhadap perilaku konsumen (Y1) sebesar 0,236 sehingga dinyatakan $\mathrm{H}_{1}$ diterima dan $\mathrm{H}_{0}$ ditolak. Dengan analisis kebijakan perusahaan (X) berpengaruh signifikan terhadap perilaku konsumen (Y1), dengan empat indikator budaya, sosial, pribadi dan psikologi sudah cukup signifikan untuk menarik konsumen membeli buku di PT. X.

\section{Hipotesis Kesebelas}

Berdasarkan hasil analisis diperoleh perilaku konsumen perusahaan (Y1) tidak berpengaruh langsung, positif dan tidak signifikan terhadap keputusan pembelian (Y2) sebesar 0,087 sehingga dinyatakan $\mathrm{H}_{0}$ ditolak. Perilaku konsumen tidak berpengaruh signifikan terhadap keputusan pembelian, ini disebabkan banyaknya judul buku yang dijual di PT. X membuat konsumen semakin selektif dalam membeli buku sehingga keputusan pembelian membutuhkan proses yang agak lama Karena berhubungan dengan daya beli konsumen.

\section{Hipotesis Keduabelas (H-12)}

Berdasarkan hasil analisis diperoleh keputusan pembelian (Y2) berpengaruh positif dan signifikan terhadap kepuasan konsumen (Y3) sebesar 0,261 sehingga dinyatakan $\mathrm{H}_{1}$ diterima dan $\mathrm{H}_{0}$ ditolak. Dengan analisis keputusan pembelian
(Y2) berpengaruh signifikan terhadap kepuasan konsumen akibat banyak informasi yang membeli buku di PT. X adalah orang-orang berpendidikan yang cukup.

\section{Hipotesis Ketigabelas (H-13)}

Berdasarkan hasil analisis diperoleh kepuasan konsumen (Y3) berpengaruh positif dan signifikan terhadap loyalitas konsumen (Y4) sebesar 0,228 sehingga dinyatakan $\mathrm{H}_{1}$ diterima dan $\mathrm{H}_{0}$ ditolak. Analisisnya kepuasan konsumen (Y3)berpengaruh signifikan terhadap loyalitas konsumen akibat adanya kesesuai kebutuhan atas buku yang di cari dan harapannya di PT. X. Dengan adanya kepuasan konsumen akan dapat mempengaruhi loyalitas konsumen.

\section{SIMPULAN}

Hasil modifikasi menunjukkan bahwa bauran pemasaran plus berpengaruh langsung, positif dan signifikan terhadap variabel pembentuknya yakni Produk sebesar 0,482, bauran pemasaran plus berpengaruh langsung, positif dan signifikan terhadap variabel pembentuknya yakni Harga sebesar 0,43 , bauran pemasaran plus berpengaruh langsung, positif dan signifikan terhadap variabel pembentuknya yakni Distribusi sebesar 0.48 , bauran pemasaran plus berpengaruh langsung, positif dan signifikan terhadap variabel pembentuknya yakni Promosi sebesar 0.641, bauran pemasaran plus berpengaruh langsung, positif dan signifikan terhadap variabel pembentuknya yakni Lokasi sebesar 0.443 , bauran pemasaran plus berpengaruh langsung, positif dan signifikan terhadap variabel pembentuknya yakni Keragaman Produk sebesar 0.992, bauran pemasaran plus tidak berpengaruh dan tidak signifikan terhadap variabel pembentuknya yakni Pelayanan sebesar 0.194, bauran pemasaran plus tidak berpengaruh dan tidak signifikan terhadap variabel pembentuknya yakni Kemudahan Mendapat Produk sebesar 0.009, Kebijakan Perusahaan berpengaruh signifikan terhadap bauran pemasaran plus sebesar 0.325 , Kebijakan Perusahaan berpengaruh langsung, positif dan signifikan terhadap Perilaku Konsumen sebesar 0.236, Perilaku Konsumen tidak berpengaruh dan tidak signifikan terhadap Keputusan Pembelian sebesar 0.087, Keputusan Pembelian berpengaruh langsung, positif dan signifikan terhadap terhadap Kepuasan Konsumen sebesar 0.261, dan Kepuasan Konsumen berpengaruh langsung, positif dan signifikan terhadap Loyalitas Konsumen sebesar 0.288 . 


\section{DAFTAR PUSTAKA}

Angipora, P, Marius. 2002. Dasar-dasar Pemasaran, Edisi Kedua, PT. Raja Grafindo Pusada, Jakarta.

Anon. 2005. Pemasaran Jasa Konsep loyalitas toko analog dengan loyalitas merek

Arbuckle, J.L., Wothke, W. 2005. Amos16. User's Guide, Small Waters Corporation, Chicago.

Fandy Tjiptono. 1997. Strategi Pemasaran, Penerbit Andi, Yogyakarta.
Ferdinand, A. 2002. Structural Equation Modelling, Dalam Penelitian Manajemen, B.P., UNDIP, Semarang.

Gitosudarmo, Indriyo, 1999, Manajemen Pemasaran, BPFE, Yogyakarta.

Hair, et.al. 2005. Mutivariate Data Analysis, Englewood Cliffs, New Jersey.

Kotler. Philips, Gary Amstrong. 1997. Dasar-Dasar Pemasaran, Jilid 1, PT. Prenhallindo, Jakarta. 